\title{
Gender Interlinked with Migration Issues in South Asian Literature and Film
}

\author{
Natasha Israt Kabir \\ Bangladesh Reform Initiative for Development, Governance and Empowerment, Dhaka, Bangladesh \\ Email: natashaisratkabir@gmail.com
}

Received 14 February 2015; accepted 1 March 2015; published 5 March 2015

Copyright $(2015$ by author and OALib.

This work is licensed under the Creative Commons Attribution International License (CC BY). http://creativecommons.org/licenses/by/4.0/

\begin{abstract}
This paper argues the urgent need to address the issue of Gender, and Migration. We have got the same perspectives in South Asian Literature and Movies that we need to come out from the stereotype idea. Migration does have the diversified phases but the question is, do the literature and movies speak a lot to showcase or portray those issues beyond dark sides? Especially in terms of gender the focus is very much biased and stereotyped with some exceptions, so this paper seeks to show the different phases of migration which does represent gender interlinked with migration in South Asian Literature and film.
\end{abstract}

\section{Keywords}

Gender, Migration, Associational Marriage/Arranged Marriage or Forced Marriage, South Asian Literature and Movies, NRI (Non Residential Indian), Bollywood Cinema, Diaspora

Subject Areas: Journalism and Communication, Sociology

\section{Introduction}

The importance of "Taking Gender Seriously" in migration research to improve migration theory and conflict research is that it seeks to open up a new era through alternative spaces for engaging in new intellectual inquiries that address the multifaceted, conceptual, methods logical and policy-related issues in the context of conflict driven migration as also to develop cross connection. "This is important not only for rectifying the wrong neglecting gender-line in the part, but equally significant for its emancipator possibilities in the future.” [1] (Enloe, Cynthia, 1989)

This literature reflection we have seen among the uprising youngsters of south Asia as well as in film making that has developed the recent trends is based on various dimension of migration focusing on internal and external issues. 


\section{Literature Case Study: Brick Lane: A Saga of UK Based Diasporas and Migration}

Monica Ali, Bangladeshi origin and an UK citizen writes with a mixture of passion and restraint that is totally complex characters, a gripping story and it’s funny too [2] (Ali, Monica, 2003).

At the tender age of eighteen, Nazneen's life is turned upside down. After an arranged marriage to a man twenty years elder than her, she exchanges her Bangladeshi village home for a block of flats in London's East End. In this new world, where poor people can be fat and even dogs go on diets, she struggles to make some of her existence and to do her duty to husband. A man of inflated ideas and stomach, he sorely tests her compliance but Nazneen submits, as she must, to fate and devotes her life to raising her family and slapping down her demons of discontent until Karim, a young radical, steps into the picture. Against a background of escalating racial and gang conflict, they embark on an affair that finally forces Nazneen to take control of her life.

\subsection{Women, the War Story and Migration in Film}

Wars have primarily been studied as a militaristic and Gender-neutral phenomenon. Throughout the 1980, 1990s Feminist scholars revisited wars in history to study their causes and outcomes as well as the ways in which they were fought and to establish the link between patriarchy and militarization [3] (Bennet, O. J. Bexely and K. Warnock, Eds., 1995). By not focusing on the experiences of middle class refugees and their encounters with the victim, poor and female refugee, migration studies have not able to highlight the gendered and classed relationships between refugees which are integral to the understanding of gendered social relationships during times of conflict [4] (Menon, R and K Bhasin, 1998).

\subsection{Film about Refugees and Raped Women: Case Study of Bangladesh}

After the Formation of Bangladesh, a large number of films were made which highlighted the impact of the varied horrors of the war. Predominant among them were the ones related to the plight of the refugees fleeing to India. The Horrors of the rape and the raped woman as the refugee symbolizing the ravaging of a nation also became a predominant issue for documentary and commercial films aimed at raising international awareness. ${ }^{1}$

The Horrors of the rape and the raped woman as the refugee symbolizing the ravaging of a nation also became a predominant issue for documentary and commercial films aimed at raising international awareness. Starting with stop genocide by Zahir Raihan in 1971, rape was highlighted by showing the quiet, mute face of a 16 year old girl in a refugee camp. The voice over narrative explained that six men had raped her while her family was killed, and all along her face spoke volumes about her experience. The close-up of the grim, vacant face of the raped intensifies her silence making it axiomatic that she does not speak. The lingering close up of her face and body provides its own narrative, making her muteness necessary and her bodily features become the direct recipient of the spectator's look. In the process, the women in the camp are transformed into illustrations of the raped women and became representative of that invisible shamed group 'The raped woman thus has various images. She is predominantly a victim who is mute has a bleak face or can only be identified through her tangled body or by the captions, which freeze her violent encounters. These images of muted victims predominantly help to legitimize the refugee image of the raped. On the other hand as the refugee who is seeking to escape the ravages of war, she can only be identified as mentally unstable and hence has to be protected by a fellow refugee who is seeking to escape the ravages of war, she can only be identified as mentally unstable and hence has to be protected by a fellow refugee who is also trying to escape the war. As a result there is already a hierarchy of refugee trauma in operation here where the image of raped refugee women excoriated the pain of other fellow refugees. This pain also allows fellow refugees to acquire and agency vis a vis the victim raped woman [5] (Waller. and J. Rycenga, Eds., 2000).

\subsection{Muktir Gaan and the Heterogeneity of Migrants Identification}

While migration studies have predominantly focused on women, the figure of the refugees and migrant has been primarily treated as a non person. This particularly gets exacerbated with the infantilizing model that is used

\footnotetext{
${ }^{1}$ While searching for his brother, an intellectual who was picked up from his house in December 1971, in Mirpur, Dhaka in January 1972 , Zahir Raihan disappeared. He is alleged to have been killed by pro-Pakistani Biharis in Mirpur. This paper does not attempt to provide an exhaustive understanding these other such film, but film example includes Deepa Mehta’s Fire, Mira Nair’s—“Mississippi Masalah”, Gurinder Chadhha's_- “Bend it like Beckham” and "Bhaji on the Beach”.
} 
while referring to refugees from Bangladesh fleeing the horrors of the 1971 war. "This is precisely reflected in the comment of the young woman with which this slogan 'Muktir Gaan' started by focusing on middle class men and women of varied religious backgrounds assigned with the agency of raising morale during war, it is able to interrupt the binaries of agent-victim, male-female and class, namely of the poor, ravaged, migrant woman who might be assigned her agency, with which migrant woman who be as-signed her agency, with which migration studies have predominantly been concerned.” [6] (Mookherjee, Noyonika, 2006) Thus while migration is seen to result in the breakdown of the processes of economic development, this paper highlights how romanticism linked to the idea of the adventure of war reveals the political economy of migration, namely who can migrate and under what condition and narratives of experiences during the war as well as after the war living this out.

Migrant experiences were initially not been made part of the accounts of war as they were seen to represent no real elements of various. "Recent feminist accounts of the war have however made gendered and migrant experiences central to an understanding of the war history.” [7] (Cooke, M and Rustoomji-kerns, Eds., 1994)

\subsection{Construction of the Subaltern within Migration Studies}

However the construction of the migrant has primarily been that of the poor, migrant women- as a romantic under class who needs to be represented either as a victim or with agentive subjectivity the paper unpicks the triad of subalterns: the poor, woman in migration studies, Bangladesh within South Asian studies and the poor and the rapid within conflict studies. These entire three subalterns are fused together in the context of the Bangladesh war of 1971. Yet during wars there are varied migrant experiences which do not fit the subaltern as imagery and hence are not included within academy and policy understandings of refugees' experiences.

Muktir Gaan is the lens through which this paper seeks to highlight the heterogeneity of migrant experiences as a result of war, and the juxtaposition and encounters between various refugees, thereby examining identification with varied refuges, subjectivities in contemporary Bangladesh. The film includes an interrogation of the victim-agent, class and gendered bin with through which migrant experiences are predominantly studied.

"The relationship between militarization and patriarchy innately studied. The relationship between militarization and patriarchy is also dislocated, and that the experience of wars could be sensual and erotic is also highlighted. Thus it shows that accounts of wars for different migrant communities also differ.” [8] (Elshtain, J. B. 1995)

Through this the paper attempts to examine the kind of migrant experience that are not addressed within migration studies and analyze discursively and reflexively the need for researchers to study migrant experiences through existing bin arises, and the modes of identification that are connotative in such studies. "Without an account of the multiplicity of migration experiences, what remain obscure is the gendered and classed relationships between refugees, something which is integral to the understanding of gendered social relationships during times of conflict.” [9] (Tickner, J. A. 1992)

\subsection{Gender and Nation in the South Asian Diasporas: Transnational Cultural Spaces in Cinemas and Literature}

The stereotyping is not giving the proper message gender interlinked with migration in South Asian film and literature. The migration is interlinked with success, with the dedication and hard work of those people who do represent the South Asian community. Auto biography and inspirational assessment are very few in number. South Asia is not all about forced marriage especially among the Indian, Pakistani and Bangladeshi and in most of the cases the story is not all about the gender who are the medium of forced marriage or the victim of illiteracy and poverty or being ignored even in abroad due to their vulnerability.

There are very few case studies of stereotyping that I observed form the other South Asian countries especially from Srilanka, Afghanistan, Nepal, Maldives and Bhutan. Most of the cases are from the below mentioned countries and from the perspectives of their literature and film especially from India, Pakistan and Bangladesh.

Even the researcher do analysis from the Film based on "The kite Runners" by Khaled Hussaini and including the movie it does have some other messages which does give another perspectives of war torn country and gender has got very little but a significant contribution to play being a migrant in another country which is a common story for a war torn country like Afghanistan.

In terms Srilanka, Maldives, Bhutan and Nepal there are very significant and popular contribution which does 
show the clear perspectives of how Gender is interlinked with Migration in South Asian Film and Literature. That does not mean they don't migrate outside their respective countries. But the migration based South Asian film and literature do depict the cases mostly from Indian subcontinent which does share common values, norms, culture, economy society.

Srilankan migration history is mainly based on Tamil community, which is another perspective of a war torn country but not like Afghanistan, but they do have very few reflections in South Asia based film and literature and being more global and reflective as like Indian subcontinent.

Nepal do have a history of migrant community where female do play an important role in terms of working force but literature and film based reflections are not like Indian subcontinent based three countries. Though the cases of being trafficked in the newspapers while migrating from Nepal to India having the assurance of job by the pimp and others they are sold in the brothel specially in Mumbai which has got a reflection in the film of Mira Nair known as "Salam Bombay" and same cases for Bangladeshi girls also having a tagline of "Sold" in the red light areas of Mumbai and in Middle East. Same stories for the Indian and Pakistani girls who do mostly migrate for a better life but later being cheated and after being sold out for flesh trade their another saga of agony starts which is another dark side of migration.

The history of Bhutan and it's migrational aspect is different than others even it does not mean that they don't migrate. But the issue of being affected due to war and victimization of trafficking is a rare case and hot tourist destination as well as land of "Gross National Happiness". They are not that much vocal in terms of literature and Film which is interlinked with gender.

Maldives do have other perspectives where other South Asian Countries workers do migrate in and do have hundred percent homogenous community including 98\% literacy and the most desirable tourist destination and not war affected like the major countries in South Asia and trafficking is rare case.

\subsection{Construction of the Feminine in Cinema}

The characterization female is most common which is fragile and vulnerable or joint family decides and forces for associational marriage but the question is the perspectives are changing day by day and it is not all about forced marriage and migration due to poverty. There are some people who are successful in terms of leadership, business, new generation phenomenon, entrepreneur, CEO and spokesperson as political leader. From the common phenomenon of those stereotyping what we can assess that South Asia is all about patriarchy where the reflection is based on female are supposed to be victim and all the seniors are dominating in terms of characterization and they are victim in terms of social, religious, economical, value and faith based society and not vocal apart from their role as housewives and having role of reproduction. But the question is the characterization does give the perspectives of same misleading and media hype based notions that is reflected in the western media and literature. So where have all those girls gone who do have success and icon of the community in abroad. Mostly the depiction of characters are based in US and UK but there are some unfold and untold stories of other communities also as we have seen by VS Naipaul even he is an exceptional case. The history of Malaya Indian is different from the community who are based in UK and restaurant based business is a trademark for them.

\subsection{The Track of Trafficking Another Saga of Migration and Also Skilled and Unskilled Labor Forces Based Migration}

Migrations do have shadow and light, the shadows are becoming more visible day by day and surpassing the light and moving faster and faster. The dark shadow of trafficking is threatening the temporary form of migration that is mostly known as migrant workers through victimizing the female being sold as a sex slave mostly in the countries of Middle East, i.e., KSA, UAE and other trafficking zone as well as being a migrant workers they do live and lead a miserable life which does know no bound. The horrible saga of inhuman lives of both the male and female migrant workers can't be explained in a sentence whereas women are more vulnerable and become a part of sexual object and can't come back to her normal life where the laws are not in favor of them. The triangle of this trafficking is based in Bangladesh-India-Pakistan. The interesting fact is that the agents who are involved in this network either they were sold once or they are doing it having profit even though they are women. But the reflection in film and literature is very few in terms of number apart from media. The women and the teenagers who are the victim mostly do engage themselves and forced to be a in flesh trade without having any option at the end leaving behind their parents, husband, children and extended family if they are married. 
Some of them do work as domestic workers facing the sexual harassment and being ill-paid and underprivileged. The economic insecurity does push them in severe uncertainty in abroad in those mentioned countries of Middle East especially. Sometimes even they do manage to come back but can't disclose anything due to societal taboo so at the end the justice cries all alone and do live like " 100 years of Solitude". Being endangered victimized and sexual object and subject female migrant workers are the most subjugated one in this patriarch world and society. The traffickers are the strongest and united network which does threaten the entity of law enforcement committee and surprisingly the story of "Internal Affairs" is under the shelter of the political leaders these are happening and unfortunately this is not the plot of the film but the reality of South Asia.

\section{Conclusions}

In most of the cases, the focused countries, where South Asian film and literature is based, are India, Pakistan and Bangladesh who are one of the most influential community in both US and UK and also as migrant workers in UAE, KSA, Malaysia, Singapore and in some of the African countries, i.e. reunion, Madagaskar, Kenya, South Africa, Mauritaus and in other parts located to the shore of Indian Ocean and in Caribbean island due to colonial legacy. Each and every community does have different perspectives of stories and cases as well as saga of being a Diaspora or belonging to the second generation and cultural integration.

"Also called immigrant and Diaspora fiction-basically, fiction about Indians, Pakistanis, Sri Lankans or Bangladeshis living outside their countries of origin (this essay decidedly excludes writing from and about the Indian subcontinent itself-which, as a recent New York Times Sunday Book Review feature reveals, is as vibrant as ever). In the early 2000s, after the success of Jhumpa Lahiri's Pulitzer Prize-winning Interpreter of Maladies, the literary market went stark-raving mad for brown-people-with-identity-crises-novels. Sure, people already knew a bit about India and Pakistan and that other place on their shirt label, but not how those people lived, what they thought about, how they loved, or what they ate. These novels presented a hushed, exotic world suddenly opened up to Westerners. Glasnost with silk rugs and Bollywood culture.” [10] (http://publishingperspectives.com/2014/06/the-17-elements-of-a-bad-south-asian-novel/)

\section{References}

[1] Enloe, C. (1989) Gender makes The World Go Around. In: Enloe, C., Ed., Bananas, Beaches and Bases: Making Feminist Sense of International Politics, Pandora Press, London, 1-18.

[2] Ali, M. (2003) Briclane. Black Swan Publications, London.

[3] Bennet, O., Bexely, J. and Warnock, K. (Eds.) (1995) Arms to Fight, Arms to Protect: Women Speak out about Conflict. Panos, London.

[4] Menon, R and Bhasin, K. (1998) Borders and Boundaries: Women in India’s Partition. Kali for Women, New Delhi.

[5] Waller, M. and Rycenga, J. (Eds.) (2000) Frontline Feminisms: Women, War and Resistance. Routledge, Cornwall.

[6] Mookherjee, N. (2006) Muktir Gaan, the Raped Women and Migrant Identities of Bangladesh War. In: Gender, Conflict and Migration, Sage Publications, New Delhi, 71-96.

[7] Cooke, M and Rustoomji-Kerns, R. (Eds.) (1994) Blood into Ink: South Asian and Middle Eastern Women on War. Westview Press, Colorado.

[8] Elshtain, J.B. (1995) Women and War. University of Chicago Press, London.

[9] Tickner, J.A. (1992) Gender in International Studies: Feminist Perspectives on Achieving Global Security. Columbia University Press, New York.

[10] http://publishingperspectives.com/2014/06/the-17-elements-of-a-bad-south-asian-novel/ 